Ann. Biol. anim. Bioch. Biophys., 1977, 17 (6), 991-995.

\title{
RNA and protein contents in the flesh of the Teleost Channa punctatus Bloch during growth.
}

par S. MUSTAFA, A. K. JAFRI

Section of Ichthyology and Fisheries, Department of Zoology, Aligarh Muslim University, Aligarh 202001, India.

\begin{abstract}
Summary. Changes in RNA and protein concentrations were studied in the flesh of the freshwater murrel Channa punctatus Bloch during growth. The patterns of change in RNA and protein contents were strikingly similar, although modifications in the latter were less pronounced. The decline in the levels of these two constituent in specimens of the 1 + age group seemed a consequence of attainment of maturity, while increase in their concentrations in succeeding year classes was the result of ingesting a high-protein diet. The increase in the logarithm of protein content was associated with a direct increase in RNA content logarithm. The correlation coefficient $(r=0.917)$ for this relationship was significantly high $(P<0.001)$.
\end{abstract}

\section{Introduction.}

Studies on the growth of natural fish populations constitute an important aspect of many applied problems of fisheries management. Since growth of fish is influenced by a combination of physiological and ecological factors, age cannot be taken as the only criterion for its assessment. Fish growth, therefore, can be visualized as a series of growth stanzas which are entered by physiological and ecological size thresholds and within which increase in size or flesh is the basic determinant of both physiological and ecological opportunity for growth (Parker and Larkin, 1959). As this increase in size or flesh is accomplished through the synthesis of body constituents, chiefly protein, measurement of protein and RNA, the protein synthesis organizer (Bulow, 1970), are useful criteria for assessing the growth process. The present paper provides an account of the dynamics of RNA and protein change in the flesh of Channa punctatus Bloch (a freshwater fish from northern India) in relation to its growth.

\section{Material and methods.}

Live specimens of Channa punctatus were caught by cast nets from the freshwater ponds at Aligarh (Lat. 27034'26" N, long. 7804'26" E), brought to the laboratory aquaria $(95 \times 35 \times 45 \mathrm{~cm})$ and allowed to rest for $24 \mathrm{hrs}$ before sampling. Water 
at a temperature of $13-16^{\circ} \mathrm{C}$ was supplied to the aquaria and the dissolved oxygen concentration varied between 5.0-6.5 ppm.

Sampling was carried out in the month of March when fish gonads commence to ripen.

At the time of investigation, the specimens were taken out of the aquaria and classified into different size groups corresponding to age : $7.5-9.0 \mathrm{~cm}\left(0^{+}\right), 11-13.8 \mathrm{~cm}$ $\left(1^{+}\right), 15.2-18.0 \mathrm{~cm}\left(2^{+}\right), 19.0-19.9 \mathrm{~cm}\left(3^{+}\right), 21.2-22.0 \mathrm{~cm}\left(4^{+}\right)$, and $23.3-23.9 \mathrm{~cm}\left(5^{+}\right)$. Total length was measured from the tip of the snout to the longest caudal fin ray, while age was determined by counting the number of annuli on the scales. The body weights of individuals of the $0^{+}, 1^{+}, 3^{+}, 4^{+}$and $5^{+}$age groups were $9.5-12.0 \mathrm{~g}, 16.2-27.0 \mathrm{~g}$ 44.0-70.4 g, 76.3-88.1 g, 97.5-108.2 g, 128.1-136.4 g, respectively.

The fish specimens were decapitated and the muscle samples removed from the epaxial portion in the region of the trunk. The tissues were freed from the skeletal elements and processed separately for chemical estimations. Seven specimens of each age group formed the basis of the present study.

RNA was assayed according to the orcinol method described by Schneider (1957). Using purified yeast RNA as a reference, we prepared a standard curve relating optical density to micrograms of RNA. Protein was estimated by the method of Lowry ef al. (1951). Using processed bovin serum albumin as a standard, we prepared the calibration curve by relating color intensity to different protein concentrations. For all these estimations color intensity was read on a Bausch and Lomb Spectronic 20 Spectrophotometer. RNA and protein values were expressed as $\mu \mathrm{g} / 100 \mathrm{mg}$ tissue and $\mathrm{mg} / 100 \mathrm{mg}$ tissue, respectively, on fresh weigh basis.

\section{Results.}

The concentrations of RNA and protein in the flesh of Channa punctatus of successive age groups from $0^{+}$to $5^{+}$are shown in figure 1 . As demonstrated by the data, RNA concentration declined from $119.643 \mu \mathrm{g} / 100 \mathrm{mg}$ in the $0^{+}$age group to $100.195 \mu \mathrm{g} /$ $100 \mathrm{mg}$ in the subsequent year class when the fish attained sexual maturity ; thereafter, the values continued to increase with the growth of the fist. In the specimens of the $5^{+}$age group, the concentration of RNA thus rose to $158.158 \mu \mathrm{g} / 100 \mathrm{mg}$.

The trend of the change in protein concentration in the various year classes of Channo punctatus was basically similar to that of RNA, except that protein change was less drastic (fig. 1).

The attainment of old age was characterized by relatively little modification in either RNA or protein.

Within the range investigated, the concentrations of RNA and protein appeared to maintain a direct proportionality. The logarithmic transformation of this relationship was expressed by the following regression equation :

$\log X=-2.4613+3.6492 \log Y$

where $X$ was the $\mu \mathrm{g}$ RNA/100 $\mathrm{mg}$ tissue, and $Y$ was the $\mathrm{mg}$ protein/100 $\mathrm{mg}$ tissue.

The correlation coefficient, $r(0.917 \pm 0.037)$ for this relationship was found to be statistically significant $(P<0.001)$. 


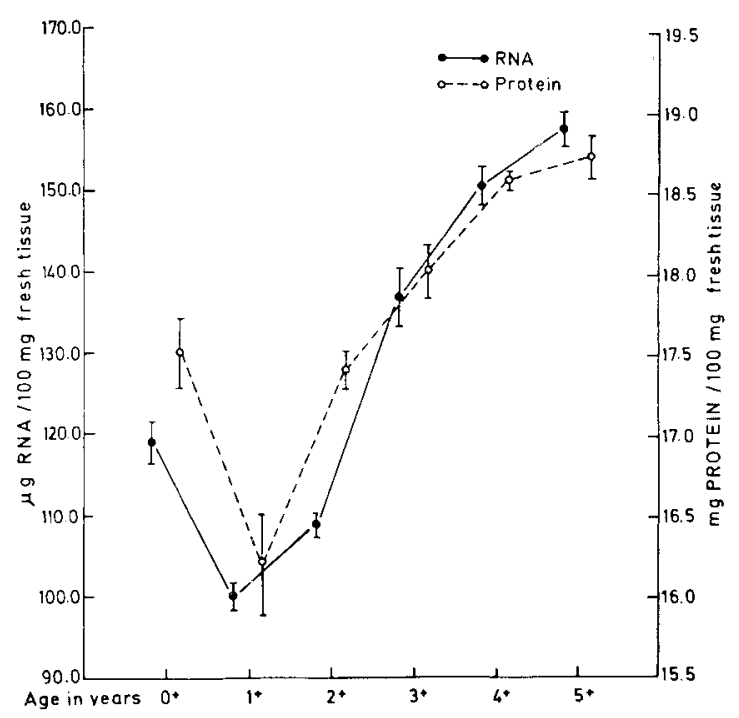

FIG. 1. - Changes in the RNA and protein concentrations in the fiesh of Channa punctatus during growth (circles represent miean; vertical lines indicate standard error).

\section{Discussion.}

Fish growth is a result of food intake, assimilation and incorporation in the body. It is largely a function of an increase in the amount of protein and of the RNA which plays a key role in protein synthesis. The presence of substantial quantitaties of RNA in tissues synthesizing large amounts of protein for either growth or multiplication, has been reported by Brachet (1955).

The striking similarity observed in the pattern of RNA and protein variations in Channa punctatus of various year classes points to the existence of a close quantitative relationship between the two ; this is associated with different growth characteristics.

The period of most rapid growth, occuring before the onset of sexual maturity in young fishes of the $0^{+}$age group, was associated with higher RNA levels and more intense synthesis of a considerable quantity of protein than in fishes of the succeeding year class. The utilization, in pre-maturity stage, of the major portion of food intake for the synthesis of protein in preference to other organic constituents, has been know to occur in many fish species (Nikolsky, 1963). The faster growth of young specimens has been regarded as an adaptative property which, besides offering protection against predators by virtue of increased size (Nikolsky, 1963), has also been reported to enable the fish to withstand extreme fluctuations in environmental temperature by slowing down the rate at which the temperature of the body tissues responds to changes in water temperature (Hoar, 1955).

Decline in the values of both RNA and protein in the flesh of the fishes of $1+$ age group coincided with the onset of sexual maturity, whence a considerable part of the food consumed by the fish was diverted to gonad building. Evidences of RNA loss 
from the fish flesh during maturation have also been presented by Creelman and Tomlinson (1959) and Bhushana Rao (1965). The depletion of muscle protein as a result of maturation has, however, been well documented (McBride et al., 1960 ; Khawaja and Jafri 1967a, $b, 1968)$.

The increase in the RNA and proiein concentrations observed in the flesh of succeeding age groups (from $2^{+}$onward) was evidently the consequence of ingesting a high-protein diet which comprised mainly forage fishes. Tandon (1962) has reported this changeover in dief in Channa punctatus. There was a marked reduction in the proportion of plant material and increase in the animal matter in the diet. The food of fishes belonging to $0^{+}$and $1^{+}$age groups was composed chiefly of aquatic macrovegetation, algae, insects, microcrustaceans, gastropod shells and, to some extent, forage fishes ; the food of larger specimens belonging to successively higher age groups consisted mainly of forage fish, macrocrustaceans (prawns), frogs, insects, and very small proportions of plant material and gastropod shells. The substifution of plant matter and gastropod shells by the animal matter in the diet of the fishes of higher age groups obviously increased dietary protein ; this was responsible for increasing RNA and protein concentrations in the flesh. Brachet (1955) has concluded that body RNA content could be determined mainly by the protein content of the diet, and that protein synthesis was related to the dynamics of RNA level change. Loss of RNA and protein from the body with consequent slowing down or even complete cessation of growth during protein-free diet or fasting, as reported by Leslie (1955) and Bouche, Creach and Gas (1970), give further support to the present findings on Channa punctatus.

Relatively little change in the concentrations of RNA and protein in the advanced age group $\left(5^{+}\right)$was obviously accompanied by the considerable drop in fish growth rate. Marked decline in the growth rate of this fish at this stage of life has indeed been reported by Qasim and Bhatt (1966). This was invariably the outcome of a modification in the ratio of maintenance to growth-food, expressed by an increase in the relative amount of maintenance food, known to characterize the period of old age in fish.

Reçu en février 1977.

Accepté en juin 1977.

Acknowledgements. - The authors are grateful to Professor S. Mashhood Alam, Head, Department of Zoology, Aligarh Muslim University, Aligarh for encouragement and the loan of his laboratory facilities. One of us (S. M.) wishes to thank the Council of Scientific and Industrial Research, New Delhi for a research fellowhip award.

Résumé. Les changements dans les concentrations en ARN et en protéines de la chair du poisson d'eau douce Channa punctatus Bloch ont été étudiés durant la croissance. Les profils d'évolution des concentrations en ARN et en protéines sont extrêmement semblables, bien que les changements des protéines soient moins accusés. La diminution des teneurs chez les animaux de 1 an paraît être une conséquence de l'établissement de la maturité sexuelle. L'augmentation ultérieure de la concentration résulte de l'acquisition d'un régime à teneur protéique élevée. L'augmentation du logarithme de la teneur protéique est très hautement corrélée avec l'augmentation de la teneur en ARN ( $r=0,917, P<0,001)$. 


\section{References}

BHUSHANARAO K. S. P., 1965. Biochemical studies on red and white muscles of Caranx sexfasciatus Quoy and Gaimard. Proc. Indian Acad. Sci., 62, 87-91.

BOUCHE G., CREACH Y., GAS N., 1970. Fasting and re-nutrition of carp (Cyprinus carpio L.). I. Influence on the nucleic acids of the liver. Arch. Sci. Physiol., 24, 243-251.

BRACHET J., 1955. The biological role of the pentose nucleic acids, 475-519. In : CHARGAFF E., DAVIDSON J. N., The nucleic acids, chemistry and biology, Vol. 2, Acad. Press, New-York.

BULOW F. J., 1970. RNA-DNA ratios as indicators of recent growth rates of a fish. J. Fish. Res. Bd. Can., 27, 2343-2349.

CREELMAN V. M., TOMLINSON N., 1959. Biochemical studies on sockeye salmon during spawning migration. VI. Ribose nucleic acid and deoxyribose nucleic acid. J. Fish. Res. Bd. Can., 16, 421-428.

HOAR W. S., 1965. Seasonal variations in the resistance of goldfish to temperature. Trans. R. Soc. Can. Ser., 49, 25-34.

KHAWAJA D. K., JAFRI A. K., 1967a. Biochemical changes in the muscle of the freshawater murrel, Ophicephalus punctatus Bloch during growth. Brotéria, 36, 71-84.

KHAWAJA D. K., JAFRI A. K., 1967b. Changes in the biochemical composition of the muscle of common carp, Cirrhina mrigala (Ham.) in relation to its length. Brotério, 35, 85-94.

KHAWAJA D. K., JAFRI A. K., 1968. Changes in the biochemical composition of two common catfishes (Wallagonia aftu Bloch and Mystus seenghala Sykes) in relation to length. Hydrobiologia, 32, 245-256.

LESLIE I., 1955. The nucleic acid content of tissues and cells, 1-50. In : CHARGAFF E., DAVIDSON J. N., The nucleic acids, chemistry and biology, Vol. 2, Acad. Press, New-York.

LOWRY O. H., ROSEBROUGH N. J., FARR A. L., RANDALL R. J., 1951. Protein measurement with the Folin phenol reagent. J. biol. chem., 193, 265-275.

MCBRIDE J. R., MACLEOD R. A., IDLER D. R., 1960. Seasonal variation in the collagen content of Pacific herring tissues. J. Fish Res. Bd. Can., 17, 913-918.

NIKOLSKY G. V., 1963. The ecology of fishes. Acad. Press, London and New-York.

PARKER R. R., LARKIN P. A., 1959. A concept of growth in fishes. J. Fish. Res. Bd. Can., 16, $721-745$.

QASIM S. Z., BHATT V. S., 1966. The growth of the freshwater murrel, Ophicephalus punctatus Bloch. Hydrobiologio, 27, 289-316.

SCHNEIDER, W. C., 1957. Determination of nucleic acid in tissues by pentose analysis, 680-684. In : COLOWICK S. P., KAPLANN. O., Methods in enzymology, Vol. 3, Acad Press, New-York.

TANDON K. K., 1962. Biology of Channa punctatus (Bloch) and Glossogobius giuris (Ham.). Res. Bull. Punjab Univ., 13, 257-262. 